\title{
Students Challenges in Learning English Online Classes
}

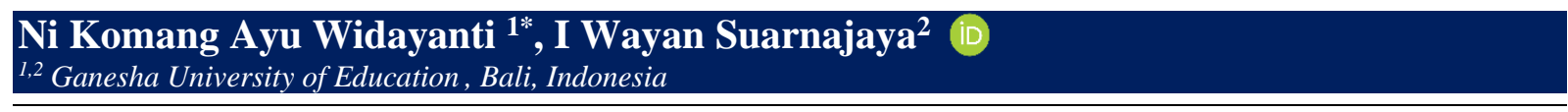

\section{A R T I C L E I N F O}

Article history:

Received April 02, 2021

Revised April 04, 2021

Accepted May 03, 2021

Available online May 25, 2021

Kata Kunci:

Pembelajaran Online, Tantangan, Bahasa Inggris

Keywords:

Online Learning, Challenges,

English

DOI:

http://dx.doi.org/10.23887/jpbi.v9 i1.34465

\section{A B S T R A C T}

\begin{abstract}
A B S T R A K
Tidak semua guru dapat mengoperasikan komputer atau gadget dalam kegiatan pembelajaran online. Masalah lainnya yaitu guru sulit untuk mengontrol setiap aktivitas dan respon siswa terhadap materi. Hal ini disebabkan tidak adanya diskusi pembelajaran dan tidak adanya siswa di tengah kelas. Tujuan penelitian ini yaitu untuk menganalisis tantangan yang diperoleh siswa selama pembelajaran bahasa Inggris online. Jenis penelitian ini yaitu kualitatif. Penelitian ini menggunakan metode penelitian kepustakaan dengan pedoman prosedur penelitian kepustakaan. Teknik yang digunakan untuk mengumpulkan data yaitu Teknik reduksi. Sumber data berasal dari artikel ilmiah. Hasil penelitian yaitu pembelajaran daring di tengah wabah Covid-19 memberikan banyak tantangan bagi para siswa untuk mengikutinya. Faktor internal dapat menjadi pemicu terjadinya masalah eksternal dan sebaliknya. Faktor internal berasal dari dalam diri siswa, yang meliputi motivasi, sikap belajar, kebiasaan belajar, dan praktik pribadi. Faktor eksternal berasal dari luar diri siswa yang berkaitan dengan lingkungan sekitar siswa. Faktor eksternal meliputi media yang digunakan siswa dan lingkungan dalam hal masalah keuangan dan lingkungan belajar. Oleh karena itu, disimpulkan bahwa pembelajaran online masih kurang efektif dan perlu solusi lebih lanjut untuk meningkatkan kualitas secara internal dan eksternal.
\end{abstract}

Not all teachers can operate computers or gadgets in online learning activities. Another problem is that the teacher finds it difficult to control every activity and student response to the material. This is due to the absence of learning discussions and the absence of students in the middle of the class. The purpose of this study is to analyze the challenges encountered during online English learning. This type of research is qualitative. This study uses library research methods with library research procedures guidelines. The technique used to collect data is the reduction technique-sources of data derived from scientific articles. The result of the study is that bold learning during the Covid-19 outbreak provides many challenges for students to follow. Internal factors can trigger external problems and vice versa. Internal factors that come from within students include motivation, learning attitudes, study habits, and personal practice. External factors that come from outside the students themselves are related to the environment around students. External factors include the media used by students and the environment in terms of financial problems and the learning environment. Therefore, online learning is still lacking, and other solutions are needed to improve the quality internally and externally.

This is an open access article under the CC BY-SA license. Copyright (C) 2021 by Author. Published by Universitas Pendidikan Ganesha.

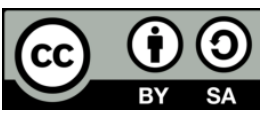

\section{INTRODUCTION}

Education has been adjusted to the pandemic to keep education running while protecting students from the dangers of COVID-19. Adaptation needs to be conducted as a response to the changing learning system from the conventional one to online learning (Almaiah et al., 2020; Mamluah \& Maulidi, 2021; Yen, 2020). The idea of adaptation originates from the simultaneous application of online learning is mandatory. It was to run education from home to make it safe and effective in terms of protection from the virus considering the role of education in precarious times like today (Chang et al., 2020; Kkese, 2020; Mailizar et al., 2020). Students' challenges are the problems faced by students, which will influence their success. Using technology as the teaching medium in this Covid-19 pandemic has many positive impacts in the field of education (Ali \& Maksum, 2020; Atmojo \& Nugroho, 2020; Baber, 2021). The use of technology as a medium for teaching and learning is commonplace and widely applied in this era. Moreover, it is really helpful to develop students' interest and understanding in learning (Chen \& Tsai, 2021; Ivanov et al., 2019). As the Indonesian President released decree number 12 the year 2020 on the 13th of April 2020 about pandemic as the national disaster, online learning becomes a must in every school.

Previous research found that not all teachers can operate computers or gadgets in online learning activities (Efriana, 2021; Hutagaol, 2021). Teachers' limited ability to maximize their knowledge on social media and gadgets to maximize learning activities. There is also a problem that it is difficult to control every activity and student response to the material (Sulistyo \& Alyani, 2021; Zain et al., 2021). It is due to the absence of learning discussions and the absence of students in the middle of the class. Students fill out the list at the beginning and 
leave the room in the middle of the class. Several studies have been conducted to investigate the challenges and difficulties in learning English through the online method. EFL Learners have found that most EFL students were not satisfied by the use of the online learning method as they did not fulfill the expected progress of doing language learning performance in that way (Mahyoob, 2020). It was also found that WhatsApp was the highest media used rather than blackboard in terms of the operating system to run the online learning class by the teachers. However, every activity shared and done in this platform caused several errors when it came to the uncontrollable message buildup. Moreover, his study showed that only $18 \%$ of 184 respondents did not find out any problems in doing online learning classes. It has been shown that $13 \%$ of the students could not access the online examination link and have internet connection problems (Mahyoob, 2020).

Supporting those ideas, previous research stated that there are several advantages and disadvantages in learning English through online media. The technical problems and individual problems were the most encountered challenges found during online learning (Ambarita, 2021; Kuama et al., 2016; Sadikin \& Hamidah, 2020). It is connected to the ability of each person to use the internet and the connectivity of the internet. Moreover, when studying English online, the teacher must improve the design and content of learning tasks from time to time when it comes to so many students and classes to be controlled. in learning online, the students must have an assistant to guide them in following the steps (Kuama et al., 2016). However, in the eye of today's problem, having assistance to do so during the pandemic seems difficult.

Online learning or E-learning is defined as a learning process, which relies on the use of technology and products such as digital technologies in wikis, blogs, podcasts, social software, and gaming technologies (Eze et al., 2018; Garavan et al., 2010). Online learning is important to conduct to protect people from the Coronavirus. An online learning environment is defined as a learning activity whose main use of computers is to share or get the information related to the material and to be conducted on an electronic-based interaction (Kyewski \& Krämer, 2018; Mpungose, 2021). Online learning is also defined as learning that is influenced more by exposure to content and instruction using digital technologies (Alshammari, 2020; Velan et al., 2015). Online learning involves students as part of teaching and learning activities. Students need to be ready and able to understand that they need to have good preparation for the learning to prepare and go through this process. Students need to adapt to this new era, which relies on electronics to conduct online learning.

Online learning has two major characteristics; blurry active learners' participation and compulsory task submissions (Alshammari, 2020; Shetu et al., 2021). Further, it is stated that blurry active learners' participation occurs because it is hard to investigate the active learners by just assessing them by writing a post in the discussion forum and doing the online test (Shetu et al., 2021). There are many factors such as mandatory assignment submissions, material courses, and internet access, and internet quota that may influence students' involvement and participation during the online learning process (Atmojo \& Nugroho, 2020; Gillett-Swan, 2017). Additionally, students face troubles due to a variety of factors such as academic abilities, internet access, and the presence of technological issues in the online learning process (Sari et al., 2020). These findings are in line with the problems that are faced by the learners in Indonesia in doing online learning. It is stated that since before the pandemic happened, online learning already had its issues, for example, the problem of internet access. The problem that students face in online learning include unstable internet connection, financial issues, and low digital literacy (Atmojo \& Nugroho, 2020).

Therefore, this research is aimed at identifying the challenges that the students obtained during online English learning. The other studies regarding the same issue have seen the problems only from the side of the teacher and the connectivity of the internet but none of them discussed the student's factors. However, this research focuses on the issues faced by the students by particularly identifying the factors and challenges obtained by students. Moreover, the problems that arose in this research seem factual and actual as they happen nowadays. Indeed, this research can help others understand what challenges occur during the online learning process so others can prevent it carefully. Other than that, this research helps improve control over the use of online learning challenges.

\section{METHOD}

This research uses library research methods using library research procedures as the guidelines. The data from previous studies would be gathered through library research. Therefore, in collecting the data, the researcher used the reduction technique to determine which data should be included and excluded. Determining some major challenges that students face in this online learning is the aim of the study with library research as the method with the literary research procedure by (Aveyard, 2014).

Data for the analysis were gathered from various published articles on Google Scholar and ResearchGate. The articles collected were used from 2000 to 2020. Some journals were chosen that were related to the factors that determined challenges in learning English during online learning in Covid 19 Pandemic outbreak in Indonesia 
from Google Scholar, ResearchGate, and nationally accredited journals indexed by Science and Technology Index (SINTA) from the Ministry of Research and Technology/ National Agency of Research and Education of Indonesia.

To support this research, some additional information was also gathered from several books. The sources chosen were important to the subject of this report, which was English online learning in the Covid-19 pandemic. The results of this research are categorized into two major groups, namely: 1) The internal factors that include motivation, attitude, personal practice, also study habits; 2) The external factors that include finance and the study environment.

\section{RESULT AND DISCUSSION}

\section{Result}

Online learning that is conducted in different situations creates different challenges among students. It is also considered differently regarding the effectivity during this pandemic era. The major point that students want in online learning is the learning to be interactive (Gamage et al., 2014). The offline learning the students interact directly face to face with their friends or teacher, but the interaction is done with intermediaries in the shape of students' gadgets. Ability in learning language, especially English for each student are different. Learners might have the same communicative goals but the performance in delivering and learning the language are different (Hanifa, 2018; Mohammadi et al., 2020). These differences are caused by some factors that come from inside and outside of the learners. Some factors that matter in language learning are coming from inside the students and also outside of the students (Ang et al., 2017). The categorization of the factors also includes motivation, attitude, and study habits. The difference is just the source of the factors. Internal factors are provided from the learners' individual ability to learn the language, meanwhile the external factors are coming from the outside situation of the learners

Table 1. Findings of Factors Influencing Students during Online Learning

\begin{tabular}{|c|c|c|c|c|c|}
\hline Problems & Motivation & Attitude & $\begin{array}{l}\text { Study Habits } \\
\text { and Personal } \\
\text { Performances } \\
\end{array}$ & $\begin{array}{l}\text { Financial } \\
\text { Problem }\end{array}$ & $\begin{array}{c}\text { Study } \\
\text { Environment }\end{array}$ \\
\hline $\begin{array}{l}\text { Student's } \\
\text { side }\end{array}$ & $\begin{array}{l}\text { Self- } \\
\text { encourageme } \\
\text { nt building }\end{array}$ & $\begin{array}{l}\text { Specification } \\
\text { towards what each } \\
\text { student needs to } \\
\text { gain attention }\end{array}$ & $\begin{array}{l}\text { Inadaptive to the } \\
\text { current situation } \\
\text { and still being } \\
\text { comfortable with } \\
\text { the offline } \\
\text { method }\end{array}$ & $\begin{array}{l}\text { Internet Quota } \\
\text { and Gadgets }\end{array}$ & $\begin{array}{l}\text { Hard to focus on } \\
\text { studying at home } \\
\text { because of the } \\
\text { family members } \\
\text { and situation }\end{array}$ \\
\hline $\begin{array}{l}\text { Learning } \\
\text { Process }\end{array}$ & $\begin{array}{l}\text { Innovative } \\
\text { and creative } \\
\text { learning } \\
\text { design in } \\
\text { maintaining } \\
\text { the student's } \\
\text { interest }\end{array}$ & $\begin{array}{l}\text { Negative Attitude } \\
\text { towards the } \\
\text { learning process } \\
\text { due to unrediness } \\
\text { preparation }\end{array}$ & $\begin{array}{l}\text { Lowest interest to } \\
\text { read the online } \\
\text { material }\end{array}$ & $\begin{array}{l}\text { Successful } \\
\text { connectivity of } \\
\text { the internet } \\
\text { mostly hard to be } \\
\text { maintained due } \\
\text { to several bugs } \\
\text { issues }\end{array}$ & $\begin{array}{l}\text { Lack of attention } \\
\text { and focus by the } \\
\text { students }\end{array}$ \\
\hline
\end{tabular}

The finding of the study shows a surprising result that most students, before the pandemic era, almost got no exposure in online learning which created the root on why there are many challenges that the students need to face in doing the online learning. This part shows the challenges that students face in the term of motivation, attitude, study habits and personal performance. The finding about motivation, attitude, personal practice, also the study habits are the internal factors in terms of students' academic abilities. The finding about problems in finance and the presence of technological difficulties is categorized as the external factors.

\section{Discussion}

Online learning showed a result of low motivation related to the low learning attitude in language learning (Ramkissoon et al., 2020; Satyawan et al., 2021). Losing motivation happens when students lose their time management skills because of the learning environment that does not let the learners learn in a conducive condition (Chepy et al., 2016; Suardana \& Simarmata, 2013). Online learning is of great importance to keep students motivated. Even the loss of motivation happened because of the lack of repetition when challenges happened like 
delayed voices, unclear pictures, and low signals. It is emphasized with the unsupportive situation related to the electricity that has not been distributed equally in some areas. Online learning provides many tasks to deal with deadlines which pressure students to finish the tasks and make them burn out (Ferri et al., 2020; Khalil, 2018). The impact of online learning on learners is urgently discussed nowadays. A negative research framework is shown when motivation and involvement were partially assisted, with a study mode discovered as a moderated mediator to this effect, which was greater and more important for online students as opposed to students who learn from the teacher directly. These findings have implications on how students can be engaged online and showing the fact that there is a need for educators to create online learning environments that promote learning.

Based on the previously reviewed studies, the point of motivation is related to the other factors especially in a situation that is related to the students' comfort in learning a language. The more comfortable learning could be, the higher the learning motivation that the students can get. It is suggested that the learning environment of the students provide less task-dealing, good internet connection, and a conducive learning environment. The respondents from a study showed a result that $55.17 \%$ of respondents disagreed with the fact that online learning leads to happiness (Syauqi et al., 2020). It can be seen that more than $50 \%$ consider online learning as a burdening situation. The respondents who disagreed were mostly students. Even the result of the research shows that online learning is less effective and not in line with their expectations. The explanation about the data related to students' motivation is about the way motivation is affected by the other factors. It has a big impact on student's achievement in the learning process. Online learning gives a challenge in the form of low motivation of the students due to the lack of comfort that the students experience. In addition, comfort is the factor that students need the most to increase their motivation to learn within the learning process. The case of "burnout" among students is the problem that triggers and becomes the concern of the parents in this online learning.

Previous research stated that they do not understand the learning processes and materials, which led them to be absent in online learning (Wijaya et al., 2020). The negative attitudes include students avoiding online learning by not attending it and wanting to hear the teacher reexplain the material because they already believed online learning is boring and tiring (Albashtawi \& Al Bataineh, 2020; Wijaya et al., 2020). During this COVID19 outbreak, it is also found that the initial capability of the students became low because online learning is likely to be biased and the preparation is only in a short time (Aji, 2020; Dewi, 2020). It creates unreadiness for the students to do the online learning. Being biased means that online learning creates a different understanding and the meaning of the materials is understood differently by the students. The short time of preparation that the students have created dissatisfaction for them and lead them to consider that online learning is not credible.

This unreadiness creates a bad attitude towards online learning (Aji, 2020; Windhiyana, 2020). The insufficient learning facilities and systems are shown by most of the universities that do not prepare their students to do online learning. A negative learning attitude due to the unconducive learning environment is caused by the students having a noisy learning environment at home. When the teachers give the students many tasks to deal with and the parents who insist on the students doing house chores when learning at their home, students will have a negative learning attitude. A negative attitude to learning can also be seen from the students' beliefs concerning their prospects. Students consider doing online learning as something that just keeps them busy without giving the real direction into what kind of future that students want to target. The findings from the previous studies show that students have a bad learning attitude since the unreadiness in the learning process. It is related to the facilities and the student's readiness that are not in a good condition. Students lose their focus and belief towards online learning, which is caused by the situation that they consider to be not supportive to improve their understanding and learning performance.

Regarding the status of Indonesian students' reading literacy that shows unsatisfying results, it is closely related to the background that Indonesian families did not use to tell stories or read books when the children are still at a young age (Rubini et al., 2018; Wusqo et al., 2021). It is shown that the students are only reading their book when the time to get examination is coming or just merely for fulfilling the assignment, not to understand the context or materials. It can be seen that until now students still have issues with study habits, especially in reading habits. Lack of reading habits could be an indicator of a bad study habit. Reading is a crucial activity that we use to acquire data and understand the materials in learning English (Albashtawi \& Al Bataineh, 2020; Zahra \& Fitrawati, 2017). The students with low ability in understanding the subject will most likely be left behind in this online learning because it is hard to give them extra explanation and guidance due to the limits of online learning, which results in a low study motivation in this era.

Online learning, which relies heavily on the use of internet connection, forces parents to provide their children gadgets, internet quota, and a stable network connection (Andel et al., 2020; Atmojo \& Nugroho, 2020; Laksana, 2020). In short, these facilities that the parents need to provide will cost the parents money to make it complete (Nartiningrum \& Nugroho, 2020; Suciati, 2017). In an era that makes it difficult to find a job, financial problems are an external factor of challenges. In the situation, where the parents cannot provide a private smartphone for their children, some of their parents are working as farmers who are not financially stable. In this situation, parents are the ones that students rely on. Parents need to provide a quote for those who are not using a 
WIFI connection. It is one of the issues in financial problems in which the parents cannot provide a big amount of quota. Another challenge is also the provision of gadgets as they are one of the must-have items for the students to do online learning.

A conducive learning environment is needed to do online learning (Adedoyin \& Soykan, 2020; Patricia, 2020). Unfortunately, as long as the learning process is conducted at home, students face many challenges regarding their environment. It is difficult to provide an environment with no issues (Hermanto et al., 2021; Uzorka $\&$ Makeri, 2020). Some issues that are commonly found include the situations that the students need to take care of their younger siblings rather than learning. It is to help their family or their parents do the house chores as long as they are at home. Further, students are often distracted by their younger siblings while doing online learning. In addition, parents' activities mostly distract the students to do online learning, as long as they are home. The students believe that they also have the duty of helping the parents. These reasons cause the students to be lack focus to do the online learning. The problem is not only related to the duty as the child is at home, but the students also need to deal with the problems that are faced in some rural areas in Indonesia (Purwanto et al., 2020; Windhiyana, 2020). The data above show the study environment that students have in doing online learning. It can be seen that there are some problems highlighted in online learning including media usage, communication problem, and a non-conducive environment.

From the analysis, it can be concluded that the effectiveness of the English online learning process needs to be improved and developed as the online learning activity keeps running during the pandemic. It is shown from the analysis that it is important to maintain the students' attitude and attention during the online learning process in the new environment such as at home as it is very different from the classroom activities at school. Because of those reasons, this study appreciates any comments regarding the same issue to improve the knowledge about the online learning process and explore the best solution towards its problems and challenges.

\section{CONCLUSION}

Online learning, which is considered as the solution in this Covid-19 outbreak, provides many challenges for the students to attend. The internal factors can be the trigger for the external problems to happen and vice versa. Internal factors are coming from within the students, which include motivation, learning attitude, study habit, and personal practice. The external factors are coming from the outside of the students which are related to the students' surrounding. The external factors include the media that the students use and the environment in terms of financial problems and study environment.

\section{REFERENCES}

Adedoyin, O. B., \& Soykan, E. (2020). Covid-19 pandemic and online learning: the challenges and opportunities. In Interactive Learning Environments. https://doi.org/10.1080/10494820.2020.1813180

Aji, R. H. S. (2020). Dampak Covid-19 pada Pendidikan di Indonesia: Sekolah, Keterampilan, dan Proses Pembelajaran $\square$ Dampak Covid-19 pada Pendidikan di Indonesia: Sekolah, Keterampilan, dan Proses Pembelajaran. Jurnal Sosial \& Budaya Syar-I, 5(1), 395-402. https://doi.org/10.15408/sjsbs.v7i5.15314

Albashtawi, A. H., \& Al Bataineh, K. B. (2020). The effectiveness of google classroom among EFL students in Jordan: An innovative teaching and learning online platform. International Journal of Emerging Technologies in Learning, 15(11), 78-88. https://doi.org/10.3991/ijet.v15i11.12865

Ali, M. K., \& Maksum, H. (2020). Utilization of E-Learning-Based ICT Learning Using the Google Classroom Application During the COVID-19 Pandemic. Journal of Education Research and Evaluation, 4(4), 373. https://doi.org/10.23887/jere.v4i4.29181

Almaiah, M. A., Al-Khasawneh, A., \& Althunibat, A. (2020). Exploring the critical challenges and factors influencing the E-learning system usage during COVID-19 pandemic. Education and Information Technologies, 25(6), 5261-5280. https://doi.org/10.1007/s10639-020-10219-y

Alshammari, M. T. (2020). Evaluation of gamification in e-learning systems for elementary school students. TEM Journal, 9(2). https://doi.org/10.18421/TEM92-51

Ambarita, E. (2021). Belajar Dari Rumah (Bdr) Menggunakan Padlet Alternatif E-Learning Pada Masa Pandemi Covid-19 (Studi Kasus Di Sman 56 Jakarta). JIRA: Jurnal Inovasi Dan Riset Akademik, 2(1), 30-36. https://doi.org/10.47387/jira.v2i1.70

Andel, S. A., de Vreede, T., Spector, P. E., Padmanabhan, B., Singh, V. K., \& Vreede, G. J. de. (2020). Do social features help in video-centric online learning platforms? A social presence perspective. Computers in Human Behavior, 113(April), 106505. https://doi.org/10.1016/j.chb.2020.106505

Ang, S., Embi, M. A., \& Yunus, M. M. (2017). Strategies of Successful English Language Learners among Private 

School
Students.
Jurnal
Pendidikan
Humaniora,
$5(2)$
47-57.

https://doi.org/10.17977/um030v5i22017p047

Atmojo, A. E. P., \& Nugroho, A. (2020). EFL classes must go online! Teaching activities and challenges during COVID-19 pandemic in Indonesia. Register Journal, 13(1), 49-76. https://doi.org/10.18326/rgt.v13i1.4976

Baber, H. (2021). Modelling the acceptance of e-learning during the pandemic of COVID-19-A study of South Korea. The International Journal of Management Education, 19(2). https://doi.org/10.1016/j.ijme.2021.100503

Chang, T. Y., Hong, G., Paganelli, C., Phantumvanit, P., Chang, W. J., Shieh, Y. S., \& Hsu, M. L. (2020). Innovation of dental education during COVID-19 pandemic. Journal of Dental Sciences, 155. https://doi.org/10.1016/j.jds.2020.07.011

Chen, C.-H., \& Tsai, C.-C. (2021). In-service teachers' conceptions of mobile technology-integrated instruction: Tendency towards student-centered learning. Computers \& Education, 170(1). https://doi.org/10.1016/j.compedu.2021.104224

Chepy, I., Pasya, G. K., \& Kastolani, W. (2016). Kontribusi Motivasi Belajar Dan Kreativitas Peserta Didik Terhadap Kemampuan Berpikir Geografis. Jurnal Pendidikan Geografi, 13(1), 49-56. https://doi.org/10.17509/gea.v13i1.3308

Dewi, W. A. F. (2020). Dampak Covid-19 Terhadap Implementasi Pembelajaran Daring Di Sekolah Dasar. Jurnal Ilmu Pendidikan, 2(1). https://doi.org/10.31004/edukatif.vi1.89.

Efriana, L. (2021). Problems of Online Learning during Covid-19 Pandemic in EFL Classroom and the Solution. Journal of English Languange Teaching and Literature, 2(1). https://jurnal.stkipmb.ac.id/index.php/jelita/article/view/74

Eze, S. C., Chinedu-Eze, V. C., \& Bello, A. O. (2018). The utilisation of e-learning facilities in the educational delivery system of Nigeria: a study of M-University. International Journal of Educational Technology in Higher Education, 15(1). https://doi.org/10.1186/s41239-018-0116-Z

Ferri, F., Grifoni, P., \& Guzzo, T. (2020). Online Learning and Emergency Remote Teaching: Opportunities and Challenges in Emergency Situations. Societies, 10(4), 86. https://doi.org/10.3390/soc10040086

Gamage, D., Fernando, S., \& Perera, I. (2014). Factors affecting to effective eLearning: Learners Perspective. Scientific Research Journal (SCIRJ), 2(4). http://www.scirj.org/papers-0514/scirj-P0514139.pdf

Garavan, T. N., Carbery, R., Malley, G. O., \& Donnell, D. O. (2010). Understanding participation in e-learning in organizations: a large- scale empirical study of employees. International Journal of Training and Development, 14(3), 155-168. https://doi.org/10.1111/j.1468-2419.2010.00349.x

Gillett-Swan, J. (2017). The Challenges of Online Learning: Supporting and Engaging the Isolated Learner. Journal of Learning Design, 10(1). https://doi.org/10.5204/jld.v9i3.293

Hanifa, R. (2018). EFL Published Materials: An Evaluation of English Textbooks for Junior High School in Indonesia. Advances in Language and Literary Studies, 9(2), 166. https://doi.org/10.7575/aiac.alls.v.9n.2p.166

Hermanto, Y. B., Agustini, V., \& Srimulyani. (2021). The Challenges of Online Learning During the Covid-19 Pandemic. Jurnal Pendidikan Dan Pengajaran, 54(1). https://doi.org/10.23887/jpp.v54i1.29703

Hutagaol, A. S. R. (2021). Analisis Kesulitan Guru Matematika Kelas VII Dalam Menerapkan Pembelajaran Daring Selama Pandemi Covid-19 Di SMP Nusantara Indah. Jurnal Riset Pendidikan Matematika, 3(2). https://doi.org/10.21009/jrpmj.v3i2.22121

Ivanov, D., Dolgui, A., \& Sokolov, B. (2019). The impact of digital technology and Industry 4.0 on the ripple effect and supply chain risk analytics. International Journal of Production Research, 57(3), 829-846. https://doi.org/10.1080/00207543.2018.1488086

Khalil, Z. M. (2018). EFL Students' Perceptions towards Using Google Docs and Google Classroom as Online Collaborative Tools in Learning Grammar. Applied Linguistics Research Journal, 2(2), 33-48. https://doi.org/10.14744/alrj.2018.47955

Kkese, E. (2020). McGurk effect and audiovisual speech perception in students with learning disabilities exposed to online teaching during the COVID-19 pandemic. Medical Hypotheses, 144(July), 110233. https://doi.org/10.1016/j.mehy.2020.110233

Kuama, Intharaksa, S., \& Usa. (2016). Is Online Learning Suitable for All English Language Students? PASAA: Journal of Language Teaching and Learning in Thailand, 1. https://eric.ed.gov/?id=EJ1134684

Kyewski, E., \& Krämer, N. C. (2018). gamify or not to gamify? An experimental field study of the influence of badges on motivation, activity, and performance in an online learning course. Computers \& Education, 118, 25-37. https://doi.org/10.1016/j.compedu.2017.11.006

Laksana, D. N. L. (2020). Implementation of Online Learning in The Pandemic Covid-19: Student Perception in Areas with Minimum Internet Access. Journal of Education Technology, 4(4), 509-509. https://doi.org/10.23887/jet.v4i4.29314 
Mahyoob, M. (2020). Challenges of e-Learning during the COVID-19 Pandemic Experienced by EFL Learners. Arab World English Journal (AWEJ), 11(4). https://papers.ssrn.com/sol3/papers.cfm?abstract_id=3652757

Mailizar, M., Almanthari, A., Maulina, S., \& Bruce, S. (2020). Secondary School Mathematics Teachers' Views on E-learning Implementation Barriers during the COVID-19 Pandemic: The Case of Indonesia. Eurasia Journal of Mathematics, Science and Technology Education, 16(7), em1860. https://doi.org/10.29333/ejmste/8240

Mamluah, S. K., \& Maulidi, A. (2021). Pembelajaran Jarak Jauh (PJJ) di Masa Pandemi COVID-19 di Sekolah Dasar. Jurnal Basicedu, 5(2). https://doi.org/10.31004/basicedu.v5i2.800

Mohammadi, M., Moenikia, M., \& Zahed-Babelan, A. (2020). The role of advance organizer on English language learning as a second language. Procedia - Social and Behavioral Sciences, 2(2). https://doi.org/10.1016/j.sbspro.2010.03.747

Mpungose, C. B. (2021). Lecturers' reflections on use of Zoom video conferencing technology for e-learning at a South African university in the context of coronavirus. African Identities. https://doi.org/10.1080/14725843.2021.1902268

Nartiningrum, N., \& Nugroho, A. (2020). Online Learning amidst Global Pandemic : EFL Students' Challenges ,Suggestions, and Needed Materials. Cademic Journal of English Language and Education, 4(2), 115-140. https://doi.org/10.29240/ef.v4i2.1494

Patricia, A. (2020). College Students' Use and Acceptance of Emergency Online Learning Due to COVID-19. International Journal of Educational Research Open, 100011. https://doi.org/10.1016/j.ijedro.2020.100011

Purwanto, A., Pramono, R., Asbari, M., Hyun, C. C., Wijayanti, L. M., Putri, R. S., \& Santoso, priyono B. (2020). Studi Eksploratif Dampak Pandemi Covid-19 Terhadap Proses Pembelajaran Online di Sekolah Dasar. Jurnal of Education, Psychology and Counseling., 2(1). https://ummaspul.ejournal.id/Edupsycouns/article/view/397

Ramkissoon, P., Belle, L. J., \& Bhurosy, T. (2020). Perceptions and experiences of students on the use of interactive online learning technologies in Mauritius. International Journal of Evaluation and Research in Education. https://doi.org/10.11591/ijere.v9i4.20692

Rubini, B., Permanasari, A., \& Yuningsih, W. (2018). Learning Multimedia Based on Science Literacy on the Lightning Theme. Journal of Science Learning and Research, 4(2), 89-104. https://doi.org/10.30870/jppi.v4i2.3926

Sadikin, A., \& Hamidah, A. (2020). Pembelajaran Daring di Tengah Wabah Covid-19. Biodik, 6(2), $109-119$. https://doi.org/10.22437/bio.v6i2.9759

Satyawan, I. M., Wahjoedi, \& Swadesi, I. K. I. (2021). The Effectiveness of Online Learning Methods During the Covid-19 Pandemic. Journal of Education Technology, 5(2), 191-199. https://doi.org/10.2991/assehr.k.210203.093

Shetu, S. F., Rahman, M. M., Ahmed, A., Mahin, M. F., Akib, M. A. U., \& Saifuzzaman, M. (2021). Impactful elearning framework: A new hybrid form of education. Current Research in Behavioral Sciences, 2. https://doi.org/10.1016/j.crbeha.2021.100038

Suardana, \& Simarmata. (2013). Hubungan Antara Motivasi Belajar dan Kecemasan pada Siswa Kelas Vi Sekolah Dasar di Denpasar Menjelang Ujian Nasional. Jurnal Psikologi Udayana, 1(1). https://doi.org/10.24843/JPU.2013.v01.i01.p20.

Suciati. (2017). Interaksi Kesiapan Belajar Dan Kepuasan Terhadap Layanan Pada Pembelajaran Online Program $\begin{array}{llll}\text { Pascasarjana. } & \text { Cakrawala } & \text { Pendidikan, } & 36(1),\end{array}$ https://journal.uny.ac.id/index.php/cp/article/view/12733/pdf.

Sulistyo, R., \& Alyani, F. (2021). Analisis Kesulitan Peserta Didik dalam Pembelajaran Daring Matematika di Masa Pandemi COVID-19. Jurnal Cendekia: Jurnal Pendidikan Matematika, 5(3). https://doi.org/10.31004/cendekia.v5i3.849

Syauqi, K., Munadi, S., \& Triyono, M. B. (2020). Students ' perceptions toward vocational education on online learning during the COVID-19 pandemic. Internasional Journal of Evaluation and Reseacrh In Education (IJEE), 9(4). https://doi.org/10.11591/ijere.v9i4.20766

Uzorka, A., \& Makeri, Y. A. (2020). Academic Challenges faced by Students in Higher Education during COVID19 Pandemic. International Journal of Research and Innovation in Social Science (IJRISS), 4(7).

Velan, G. M., Goergen, S. K., Grimm, J., \& Shulruf, B. (2015). Impact of Interactive e-Learning Modules on Appropriateness of Imaging Referrals: A Multicenter, Randomized, Crossover Study. Journal of the American College of Radiology, 12(11). https://doi.org/10.1016/j.jacr.2015.06.026

Wijaya, T. T., Ying, Z., Purnama, A., \& Hermita, N. (2020). Indonesian students' learning attitude towards online learning during the coronavirus pandemic. Psychology, Evaluation, and Technology in Educational Research, 3(1). https://doi.org/10.33292/petier.v3i1.56 
Windhiyana, E. (2020). Dampak Covid-19 Terhadap Kegiatan Pembelajaran Online Di Perguruan Tinggi Kristen Di Indonesia. Perspektif Ilmu Pendidikan, 34(1), 1-8. https://doi.org/10.21009/pip.341.1

Wusqo, I. U., Khusniati, M., Pamelasari, S. D., Laksono, A., \& Wulandari, D. (2021). The effectiveness of digital science scrapbook on students' science visual literacy. Jurnal Pendidikan IPA Indonesia, 10(1), 121-126. https://doi.org/10.15294/jpii.v10i1.27130

Yen, T.-F. T. F. (2020). The performance of online teaching for flipped classroom based on COVID-19 aspect. Asian Journal of Education and Social Studies, 57-64. https://doi.org/10.9734/ajess/2020/v8i330229

Zahra, F., \& Fitrawati, F. (2017). Teaching Reading Comprehension By Using Metacognitive Strategy: Read, Ask, Paraphrase (Rap) At Senior High School. Journal Of English Education And Teaching, 6(1). https://doi.org/10.24036/jelt.v6i1.7119

Zain, N. H., Sayekti, I. C., \& Eryani, R. (2021). Problematika Pembelajaran Daring pada Peserta Didik di Sekolah Dasar. Jurnal Basicedu, 5(4). https://doi.org/10.31004/basicedu.v5i4.1051 